\title{
Autosomal dominant familial neurohypophyseal diabetes insipidus caused by a mutation in the arginine-vasopressin II gene in four generations of a Korean family
}

\author{
Myo-Jing Kim, MD', \\ Young-Eun Kim, MD', \\ Chang-Seok Ki, MD, PhD', \\ Jae-Ho Yoo, MD ${ }^{1}$ \\ 'Department of Pediatrics, Dong-A \\ University College of Medicine, Busan, \\ ${ }^{2}$ Department of Laboratory Medicine \\ and Genetics, Samsung Medical \\ Center, Sungkyunkwan University \\ School of Medicine, Seoul, Korea
}

\begin{abstract}
Autosomal dominant neurohypophyseal diabetes insipidus is a rare form of central diabetes insipidus that is caused by mutations in the vasopressin-neurophysin II (AVP-NPII) gene. It is characterized by persistent polydipsia and polyuria induced by deficient or absent secretion of arginine vasopressin (AVP). Here we report a case of familial neurohypophyseal diabetes insipidus in four generations of a Korean family, caused by heterozygous missense mutation in exon 2 of the AVP-NPII gene (c.286G > T). This is the first report of such a case in Korea.
\end{abstract}

Keywords: Arginine vasopressin (neurophysin II, antidiuretic hormone, diabetes insipidus, neurohypophyseal) protein, Human

\section{Introduction}

Neurohypophyseal (central) diabetes insipidus (DI) is characterized by deficient or absent secretion of arginine vasopressin (AVP), resulting in polyuria and polydipsia ${ }^{1)}$. It is typically caused by tumors, infection, or trauma ${ }^{2}$.

Familial neurohypophyseal DI is a rare inherited disorder accounting for $1 \%-5 \%$ of all cases of central DI. The majority of cases are inherited in an autosomal dominant pattern ${ }^{3,4}$. Familial neurohypophyseal DI is caused by a mutation in the $2.5 \mathrm{~kb}$ AVP-neurophysin II (AVP-NPII) gene located on chromosome $20 \mathrm{p} 13^{5}$. Since the first AVP-NPII mutation was reported ${ }^{6}, 62$ additional mutations have been identified ${ }^{1,7}$.

In this study, we report a case of familial neurohypophyseal DI caused by a mutation (c.286G $>$ T) in the AVP-NPII gene in four generations of a Korean family.

\section{Case report}

A 7-year-old boy was admitted to the hospital for persistent symptoms of polydipsia and polyuria that started in early infancy. He drank an average of $3.9 \mathrm{~L}$ of water per day and urinated an average of $5.1 \mathrm{~L}$ per day, including at least three times during the night; on physical examination, he was otherwise healthy. His height and weight were $123.3 \mathrm{~cm}$ (39th percentile) and $20.7 \mathrm{~kg}$ (15th percentile), respectively. His medical history was unremarkable, and he did not have a history of head trauma or symptoms of neurological or pituitary dysfunction. An evaluation of the family history revealed seven family members, spanning four generations, who were suspected of having the same symptoms for an extended period of time (Fig. 1). His father reported an intake of $11 \mathrm{~L}$ of water per day and a urine output of $12 \mathrm{~L}$ per day. His grandmother reported an intake of $10 \mathrm{~L}$ of water per day and a urine output of $9 \mathrm{~L}$ per day. The pedigree was consistent with autosomal dominant inheritance.
Address for correspondence:

Jae-Ho Yoo, MD

Department of Pediatrics, Dong-A

University College of Medicine, 32

Daesingongwon-ro, Seo-gu, Busan

602-714, Korea

Tel: $+82-51-240-5124$

Fax: +82-51-242-2765

E-mail: pedendo@dau.ac.kr 


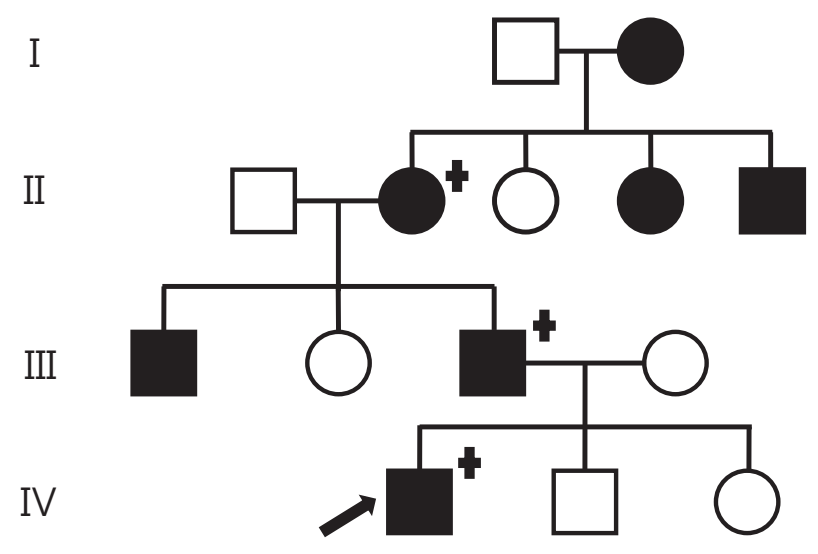

Fig. 1. Family pedigree with familial neurophyseal diabetes inspidus in four generations. The black symbols indicate an affected subject; females are indicated by circles and males by squares. The arrow indicates the proband. Genetically tested individuals are indicated by the "+"symbol.
Table 1. Basal hormone study and auxological findings

\begin{tabular}{|c|c|c|c|}
\hline Variable & Proband & Father & Grandmother \\
\hline Age (yr) & 7.4 & 33.2 & 53.7 \\
\hline Height (cm) & 123.3 & 178.0 & 155.1 \\
\hline Height percentile & 39 & $>97$ & $<3$ \\
\hline Weight (kg) & 20.7 & 80.0 & 64.5 \\
\hline Weight percentile & 15 & $>97$ & 50 \\
\hline Free T4 (ng/dL) & 1.38 & 2.15 & 1.53 \\
\hline Total T3 (ng/dL) & 169.9 & 115.2 & 150.0 \\
\hline TSH (ulU/mL) & 2.52 & 0.91 & 1.08 \\
\hline Cortisol (ug/dL) & 17.41 & - & - \\
\hline ACTH (pg/mL) & 40.23 & - & - \\
\hline IGF-I (ng/mL) & 134.16 & - & - \\
\hline IGFBP-3 (ng/mL) & 2045.24 & - & - \\
\hline S-Osm (mOsm/kg) & 278 & 290 & 297 \\
\hline U-Osm (mOsm/kg) & 55 & 133 & 394 \\
\hline
\end{tabular}

T4, thyroxine; T3, triiodothyronine; TSH, thyroid stimulating hormone; ACTH, adrenocorticotropic hormone; IGF-I, insulin like growth factor-I; IGFBP-3, IGF binding protein-3; S-Osm, serum osmolarity; U-Osm, urine osmolarity.

Table 2. Water deprivation test results for the proband

\begin{tabular}{|c|c|c|c|c|c|c|}
\hline Duration (hr) & Weight (kg) & $\begin{array}{l}\text { Urine output } \\
\text { (mL/kg/hr) }\end{array}$ & Sodium (mmol/L) & S-Osm (mOsm/kg) & U-Osm (mOsm/kg) & $\mathrm{ADH}(\mathrm{pg} / \mathrm{mL})$ \\
\hline 0 & 22.0 & 19.0 & 139 & 278 & 55 & 8.66 \\
\hline 1 & 21.5 & 7.0 & 139 & 287 & 49 & 8.22 \\
\hline 2 & 21.5 & 12.6 & 141 & 288 & 69 & 8.09 \\
\hline 3 & 21.0 & 7.1 & 140 & 289 & 111 & 7.75 \\
\hline 4 & 21.0 & 1.0 & 144 & 297 & 141 & 7.32 \\
\hline 5 & 21.0 & 12.0 & 141 & 297 & 182 & 6.3 \\
\hline 6 & 20.5 & 4.4 & 143 & 291 & 264 & 5.42 \\
\hline $7^{\text {a) }}$ & 20.0 & 3.0 & 145 & 302 & 349 & 5.62 \\
\hline 8 & 20.0 & 0.5 & 144 & 289 & 445 & 6.41 \\
\hline 9 & 20.0 & 2.5 & 145 & 294 & 543 & 6.06 \\
\hline 10 & 20.0 & 1.5 & 136 & 278 & 572 & 4.71 \\
\hline 11 & 20.0 & 1.0 & 136 & 280 & 621 & 7.19 \\
\hline
\end{tabular}

S-Osm, serum osmolarity; U-Osm, urine osmolarity; $\mathrm{ADH}$, antidiuretic hormone.

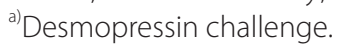

The basal plasma levels of free thyroxine, total triiodothyronine, thyroid stimulating hormone, cortisol, adrenocorticotropic hormone, insulin like growth factor-I (IGF-I), IGF binding protein-3 were within the normal ranges. The basal plasma osmolarity was $278 \mathrm{mOsm} / \mathrm{kg} \mathrm{H}_{2} \mathrm{O}$, the urine osmolarity was $55 \mathrm{mOsm} / \mathrm{kg} \mathrm{H}_{2} \mathrm{O}$, the urine specific gravity was less than 1.005 , the plasma sodium was $139 \mathrm{mEq} / \mathrm{L}$, and the antidiuresis hormone (ADH) level was $8.66 \mathrm{pg} / \mathrm{mL}$. He underwent a standard water deprivation test of sufficient duration to increase plasma osmolarity and plasma sodium above $300 \mathrm{mOsm} /$ $\mathrm{kg} \mathrm{H}_{2} \mathrm{O}$ and $145 \mathrm{mEq} / \mathrm{L}$, respectively. After seven hours, the plasma osmolarity and sodium increased to $302 \mathrm{mOsm} / \mathrm{kg}$ $\mathrm{H}_{2} \mathrm{O}$ and $145 \mathrm{mEq} / \mathrm{L}$, respectively; the urine osmolarity was $349 \mathrm{mOsm} / \mathrm{kg} \mathrm{H}_{2} \mathrm{O}$, and the ADH was $5.62 \mathrm{pg} / \mathrm{mL}$. During the test, he continued to have inappropriately dilute urine and fluid diuresis. His body weight decreased by $9 \%$. After a desmopressin challenge test of $20 \mu \mathrm{g}$, his urine osmolarity increased to 621 $\mathrm{mOsm} / \mathrm{kg} \mathrm{H} \mathrm{H}_{2} \mathrm{O}$. These results confirmed a diagnosis of partial vasopressin-deficient $\mathrm{DI}$ (Tables 1,2).

The pituitary magnetic resonance imaging (MRI) showed a relatively small and hypointense neurohypophysis (Fig. 2).

After informed consent was obtained, peripheral blood specimens were collected from the his family members for molecular genetic analysis. Genomic DNA (gDNA) was extracted using the Wizard genomic DNA purification kit according to the manufacturer's instructions (Promega, Madison, WI, USA). All coding exons and their exon-intron boundaries of the $A V P$ gene were amplified by polymerase chain reaction using primers designed by the authors (available by request). Cycle sequencing was performed with a Big Dye Terminator Cycle Sequencing Ready Reaction kit (Applied Biosystems, Foster City, CA, USA) on an ABI 3130xl Genetic 


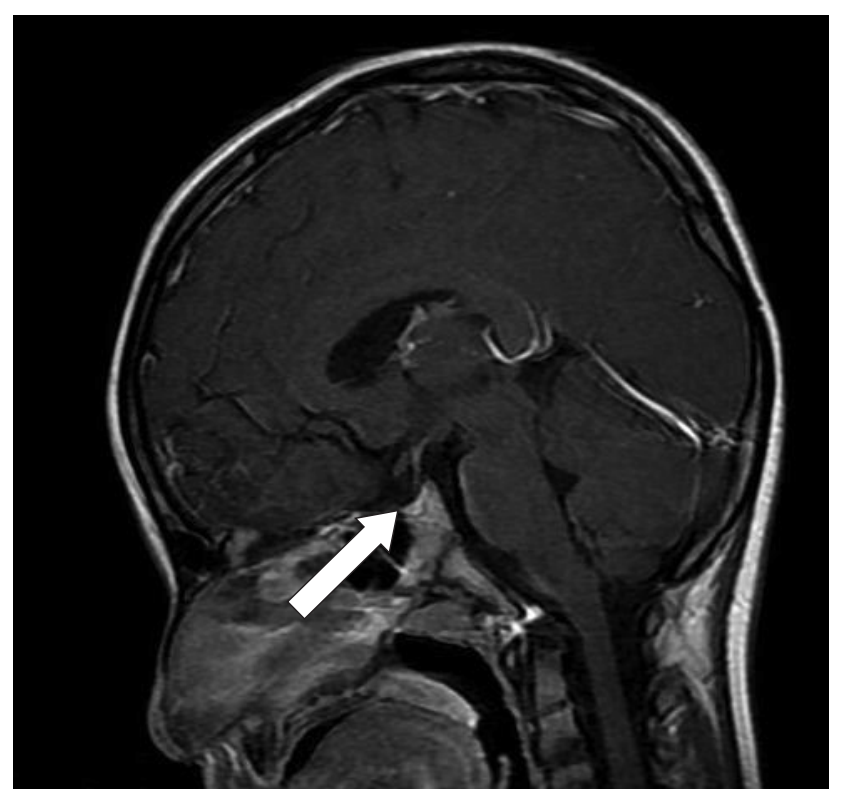

Fig. 2. The arrow indicate a relatively small and hypointense neurohypophysis in the sella magnetic resonance image.

Analyzer (Applied Biosystems). The sequencing results were compared to a reference sequence of the AVP gene, GenBank accession number NM 000490.4. The sequence variation was described according to the recommendations of the Human Genome Variation Society (http://www.hgvs.org/mutnomen/). Direct sequencing analysis of the AVP-NPII gene revealed a heterozygous c. $286 \mathrm{G}>\mathrm{T}$ mutation predicting an amino acid substitution (Gly96Cys) in exon 2. The AVP-NPII genes of the his father and grandmother were found to have the same mutation (Fig. 3).

After treatment with oral desmopressin $0.1 \mathrm{mg}$ two times daily was started, the symptoms of polydipsia and polyuria were satisfactorily controlled, resulting in a dry bed throughout the night, and an improvement in food intake and growth. In three months, he gained $3 \mathrm{~kg}$. Currently he drinks approximately $1.5 \mathrm{~L}$ of water daily and has a urine output of $1.5 \mathrm{~L}$ per day. His father and grandmother's water intake/diuresis per day are $1.8 \mathrm{~L} / 1.8 \mathrm{~L}$ and 3.0 L/2.0 L, respectively, due to the effects of the medication.

\section{Discussion}

Neurohypophyseal DI is a rare disorder of water conservation resulting from a deficiency of AVP. Under normal circumstances, the precursor hormone prepro-AVP is produced by neurosecretory cells in the supraoptic and paraventricular nuclei of the human hypothalamus ${ }^{8)}$. During axonal transport to the pituitary gland, preproAVP is cleaved to become AVP, and it is finally stored in the posterior pituitary gland (neurohypophysis). When water deprivation causes a rise in plasma osmolarity above 280-290 $\mathrm{mOsmol} / \mathrm{kg} \mathrm{H}_{2} \mathrm{O}$, AVP is released into

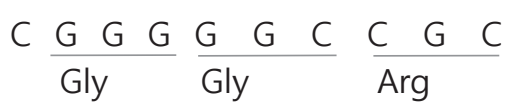

Control Allele

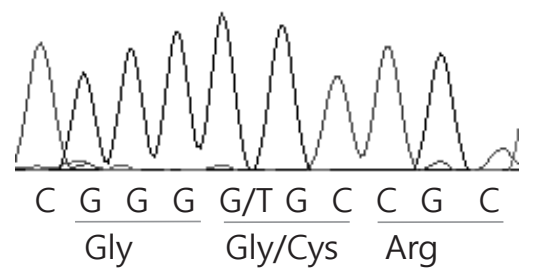

Patient Allele

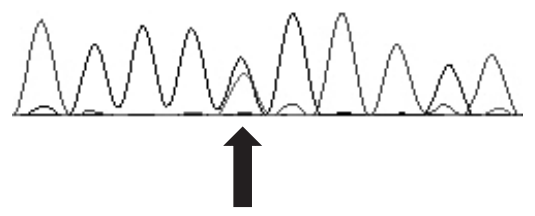

c.286G > T (p.Gly96Cys)

Fig. 3. Electropherogram of the AVP gene. A missense mutation was identified in the DNA from the proband; c.286G>T (p.Gly96Cys).

the circulation. In the collecting ducts of the kidney, AVP binds to the vasopressin type 2 receptor, inducing upregulation of the aquaporin II channels. This process results in increased water retention with a rise in urine osmolarity to a maximum of 1,000-1,200 $\mathrm{mOsmol} / \mathrm{kg}$ $\mathrm{H}_{2} \mathrm{O}$ and a restoration of plasma osmolarity to within the reference range ${ }^{1,9)}$.

Familial neurohypophyseal DI is rare disorder accounting for only $1 \%-5 \%$ of all causes of central $\mathrm{DI}^{2,10)}$. Familial neurohypophyseal DI typically presents between the ages of 1 and 6 years with polyuria and polydipsia and is radiologically characterized by the loss of the posterior pituitary bright spot on T1 MRI, suggesting dysfunction of the neurohypophysis ${ }^{11}$.

Familial neurohypophyseal DI is caused by mutations in the AVP-NPII gene, which are usually inherited in an autosomal dominant pattern $^{12)}$. The AVP-NPII gene is located on chromosome 20p13 and has three exons, with an open reading frame of $492 \mathrm{bp}$. Exon 1 encodes a signal peptide, AVP, and the N-terminal portion of NP II; exon 2 encodes the central region of NP II; and exon 3 encodes the C-terminal part of NP II and copeptin, a glycoprotein with an unknown function ${ }^{8,13)}$. The mutations involved in familial neurophyphyseal DI include small deletions, as well as missense and nonsense mutations that affect the signal peptide, the AVP moiety, or the AVP carrier protein, NPII. The majority of these mutations have been found in the region of the gene encoding NPII, an intracellular binding protein for AVP. Only a few mutations have been localized to the signal peptide or the AVP coding 
sequence, and no mutations have been localized to the glycoprotein moiety. It is assumed that all known autosomal dominant mutations cause defective folding or dimerization of the precursor protein ${ }^{14,15}$.

Since the first AVP-NPII mutation was reported ${ }^{6}, 62$ different mutations have been identified ${ }^{1,7)}$. In Korea, a splice site mutation within the intron, a missense mutation in exon $2(+1692 \mathrm{C}>\mathrm{A})$, and a deletion mutation of Glu78have been reported ${ }^{5,10)}$.

In this study, we identified a Korean family with autosomal dominant familial neurohypophyseal DI in four generations, and we identified the first heterozygous missense mutation in exon 2 of the AVP-NPII gene (c.286G $>$ T) in Asia. The proband's father, uncle, grandmother, grandmother's sister, grandmother's brother, and great-grandmother each have a long history of polyuria and polydipsia, suggesting autosomal dominant transmission of the disease. Additionally, the proband's great-grandmother might have been the first person affected and thus would be expected to have milder signs, although she was not tested for the disease. The diagnosis was confirmed in the proband by a water deprivation test and in three family members (proband, proband's father, proband's grandmother) by DNA analysis. Genetic analysis of the AVP-NPII region revealed a heterozygous missense mutation in exon 2 of the AVP-NPII gene $(286 \mathrm{G}>\mathrm{T})$, and this amino acid substitution (Gly96Cys) was predicted to have occurred in the three clinically affected subjects. The transition G286T, causing substitution of Gly96Cys, was previously reported in a case of familial neurohypophyseal DI in the United States ${ }^{16)}$.

In summary, we report a Korean family with autosomal dominant familial neurohypophyseal DI affecting four generations with a heterozygous missense mutation in exon 2 of AVP-NPII (c.286G > T, p.Gly96Cys). The presence of this mutation suggests that the portion of the neurophysin peptide encoded by this sequence is important for the appropriate expression of vasopressin.

\section{Conflict of interest}

No potential conflict of interest relevant to this article was reported.

\section{References}

1. de Fost M, van Trotsenburg AS, van Santen HM, Endert E, van den Elzen C, Kamsteeg EJ, et al. Familial neurohypophyseal diabetes insipidus due to a novel mutation in the arginine vasopressin-neurophysin II gene.
Eur J Endocrinol 2011;165:161-5.

2. Abu Libdeh A, Levy-Khademi F, Abdulhadi-Atwan M, Bosin E, Korner M, White PC, et al. Autosomal recessive familial neurohypophyseal diabetes insipidus: onset in early infancy. Eur J Endocrinol 2010;162:221-6.

3. Baylis PH, Cheetham T. Diabetes insipidus. Arch Dis Child 1998;79:84-9.

4. Kaplowitz PB, D'Ercole AJ, Robertson GL. Radioimmunoassay of vasopressin in familial cental diabetes insipidus. J Pediatr 1982;100:76-81.

5. Lee YW, Lee KW, Ryu JW, Mok JO, Ki CS, Park HK, et al. Mutation of Glu78 of the AVP-NPII gene impairs neurophysin as a carrier protein for arginine vasopressin in a family with neurohypophyseal diabetes insipidus. Ann Clin Lab Sci 2008;38:12-4.

6. Ito M, Mori Y, Oiso Y, Saito H. A single base substitution in the coding region for neurophysin II associated with familial central diabetes insipidus. J Clin Invest 1991;87:725-8.

7. Christensen JH, Rittig S. Familial neurohypophyseal diabetes insipidus: an update. Semin Nephrol 2006;26:20923.

8. Hedrich CM, Zachurzok-Buczynska A, Gawlik A, Russ S, Hahn G, Koehler K, et al. Autosomal dominant neurohypophyseal diabetes insipidus in two families. Molecular analysis of the vasopressin-neurophysin II gene and functional studies of three missense mutations. Horm Res 2009;71:111-9.

9. Robertson GL, Shelton RL, Athar S. The osmoregulation of vasopressin. Kidney Int 1976;10:25-37.

10. Tae HJ, Baek KH, Shim SM, Yoo SJ, Kang MI, Cha BY, et al. A novel splice site mutation of the arginine vasopressinneurophysin II gene identified in a kindred with autosomal dominant familial neurohypophyseal diabetes insipidus. Mol Genet Metab 2005;86:307-13.

11. Maghnie M, Villa A, Arico M, Larizza D, Pezzotta S, Beluffi $\mathrm{G}$, et al. Correlation between magnetic resonance imaging of posterior pituitary and neurohypophyseal function in children with diabetes insipidus. J Clin Endocrinol Metab 1992;74:795-800.

12. Fluck CE, Deladoey J, Nayak S, Zeller O, Kopp P, Mullis PE. Autosomal dominant neurohypophyseal diabetes insipidus in a Swiss family, caused by a novel mutation (C59Delta/A60W) in the neurophysin moiety of preprovasopressin-neurophysin II (AVP-NP II). Eur J Endocrinol 2001;145:439-44.

13. Sausville E, Carney D, Battey J. The human vasopressin gene is linked to the oxytocin gene and is selectively expressed in a cultured lung cancer cell line. J Biol Chem 1985;260:10236-41.

14. Eubanks S, Nguyen TL, Deeb R, Villafania A, Alfadhli A, Breslow E. Effects of diabetes insipidus mutations on neurophysin folding and function. J Biol Chem 2001;276:29671-80.

15. Christensen JH, Siggaard C, Corydon TJ, deSanctis L, 
Kovacs L, Robertson GL, et al. Six novel mutations in the arginine vasopressin gene in 15 kindreds with autosomal dominant familial neurohypophyseal diabetes insipidus give further insight into the pathogenesis. Eur J Hum Genet 2004;12:44-51.
16. Rittig S, Robertson GL, Siggaard C, Kovacs L, Gregersen $\mathrm{N}$, Nyborg J, et al. Identification of 13 new mutations in the vasopressin-neurophysin II gene in 17 kindreds with familial autosomal dominant neurohypophyseal diabetes insipidus. Am J Hum Genet 1996;58:107-17. 